\title{
Effectiveness of commercially available selected water-based and oil-based ethephon formulations as a yield stimulant of rubber (Hevea brasiliensis)
}

\author{
N P S N Karunarathne*, L T B K Fernando*, K V V S Kudaligama*, \\ W G D Lakmini**, N N Abewardhana*, P D T L Madushani*, M K P Perera*, \\ P Seneviratne* and V H L Rodrigo* \\ * Rubber Research Institute of Sri Lanka, Dartonfield, Agalawatta, Sri Lanka \\ ** Department of Crop Science, Faculty of Agriculture, University of Ruhuna, \\ Kamburupitiya, Sri Lanka
}

\begin{abstract}
Rubber industry plays a major role in the economy of Sri Lanka. Two types of commercial ethephon mixtures i.e. water-based and oil-based are presently marketed in Sri Lanka to use as yield stimulant of rubber. Though the yield performance of these mixtures had been studied, no proper investigation has been made on effectiveness of these two types of commercial ethephon mixtures on factors affecting latex regeneration and flow of Hevea brasiliensis.

Mature rubber plantation with RRIC 121 genotype tapped on first virgin panel (BO-I) with $S / 2 d 4$ (half spiral once in four days) system was selected for the study. Yield related factors and latex physiological parameters of rubber trees stimulated with two types of commercial ethephon mixtures were determined on each tapping day during June - August, 2018.

Daily latex volume per tree, daily dry rubber yield per tree $(\mathrm{g} / \mathrm{t} / \mathrm{t})$, latex thiol content, latex polyphenol content and plugging index showed a similar pattern of variation between the rubber trees stimulated with water-based and oil-based ethephon over the experimental period and the variations were not statistically significant. Oil-based ethephon stimulated rubber trees had a significantly higher latex dry rubber content $(43.80 \pm 0.37,42.69 \pm 0.47,42.13 \pm 0.50 \%)$ than water-based ethephon stimulated trees $(40.63 \pm 0.36,39.39 \pm 0.42,39.59 \pm 0.36 \%)$ over the three consecutive stimulation cycles. Inorganic phosphorus content in latex was found to be 21-23\% higher in trees applied with water-based stimulant than oil-based stimulant over the period studied. Oil-based stimulation showed 7-11\% increase in latex flow duration than water-based stimulation. Though some physiological parameters of latex have been improved in trees with application of oil-based ethephon, yielding capacity for a particular period was statistically comparable in trees applied with water-based and oil-based ethephon.
\end{abstract}

Key words: Hevea, low intensity harvesting, oil-based ethephon, rubber, water-based ethephon

Introduction

Rubber tree (Hevea brasiliensis) is a commercially cultivated plantation crop for industrial production of latex 
N P S N Karunarathne et al.

(Verheye, 2010). Harvesting of latex is the costliest operation in rubber plantations which has led to higher cost of production (COP) (Rodrigo et al., 2011). In addition, currently the plantations are facing difficulties such as fluctuation in rubber price, shortage of harvesters and high rate of bark consumption and these issues have made a significant impact on rubber plantation industry (Prasanna et al., 2010; Rodrigo et al., 2011). Reduction of tapping days due to rain interferences, lack of skilled harvesters, poor field conditions and improper infrastructure facilities have also affected the economic performance of rubber lands (Kudaligama et al., 2012; Rodrigo et al., 2011).

Tapping a half spiral of the tree, once in two days frequency $(\mathrm{S} / 2 \mathrm{~d} 2)$ is the traditional harvesting system of rubber in Sri Lanka (Kudaligama et al., 2010). However, in order to mitigate the above mentioned issues prevailing in rubber plantation industry, mainly high COP and lack of skilled harvesters, low intensity harvesting (LIH) systems have been introduced. These systems allow trees to be tapped in a lesser frequency or lesser amount of bark consumption and ensure sustained production in rubber plantations (Njukeng et al., 2011).

Ethephon is used as the yield stimulant along with the LIH systems in order to recover the yield loss due to the reduction of harvesting intensity (Gao et al., 2018). Ethephon is a kind of plant growth regulator that penetrates into the plant tissues and decomposes to produce ethylene that increases activities of anabolic physiological processes such as biosynthesis of rubber and related proteins (Tseng et al., 2000; Coupe and Chrestin, 1989). Ethephon induces sucrose hydrolysis in tissues, thus the carbon supply for rubber biosynthesis through increased glycolysis (Tupy, 1985; Mesquita et al., 2006). Also, released ethylene inhibits latex coagulation and avoids blockings by making walls of laticiferous vessels rigid and thickened (Shi et al., 2016). Furthermore, effect of ethephon on cell membrane permeability results in decrease of laticiferous vessel obstruction (Zhu and Zhang, 2009). As a result of delaying the plugging of latex vessels, the duration of latex flow is increased (Emuedo et al., 2017; Gao et $a l ., 2018)$. Thereby the yield per tapping is increased (Kudaligama et al., 2013).

There are two types of commercial ethephon mixtures (i.e. water-based and oil-based) which are available for stimulation of rubber trees in Sri Lanka and both are imported in ready-mixed form. Though the yield performance of different low intensity harvesting systems with oil-based ethephon had been studied previously (Kudaligama et al., 2013), factors affecting latex regeneration and flow with oil-based ethephon and water-based ethephon under Sri Lankan conditions has not been studied in detail. Therefore, this study was conducted with a view to investigate the effectiveness of water-based and oilbased ethephon on yield and factors affecting latex regeneration and flow of Hevea brasiliensis under Sri Lankan conditions.

Materials and Methods

Mature rubber field replanted with RRIC 
121 Hevea genotype and tapped on first virgin panel (BO-1) with $\mathrm{S} / 2 \mathrm{~d} 4$ (half spiral, once in four days) tapping system at Galewatte Division of Dartonfield Estate in Kalutara district was selected for the study. Two commercial ethephon mixtures, water-based and oil-based currently marketed in Sri Lanka were selected as the treatments. Randomized complete block design (RCBD) with three replicates was used and three subsamples from each replicate were used for sampling. For each sub-sample ten trees with equal vigour had been randomly selected. As per the recommendation for $\mathrm{S} / 2 \mathrm{~d} 4$ system, trees were stimulated monthly by applying 1.6 $\mathrm{g}$ of $2.5 \%$ ethephon per application per tree (Rodrigo et al., 2011). Important yield related factors such as daily latex volume per tree, dry rubber content of latex (Anon., 1984), daily dry rubber yield per tree $(\mathrm{g} / \mathrm{t} / \mathrm{t})$, latex flow duration and plugging index (Milford et al., 1969) were determined on each tapping day after stimulation with the two different types of ethephon during June - August, 2018.

Latex samples were collected to the vessels immersed in ice, avoiding latex dripped for the initial five minutes after tapping. Serum was extracted by coagulating $2.5 \mathrm{~g}$ of latex in $25 \mathrm{ml}$ of $2.5 \%$ trichloro acetic acid (TCA) and used for testing latex physiological parameters.

\section{Determination of sucrose content}

Test samples were prepared by diluting $0.1 \mathrm{ml}$ of latex serum with $0.4 \mathrm{ml}$ of TCA. Sucrose content was determined using the anthrone method described by
Scott and Melvin (1953). Absorbance of the samples were measured at $620 \mathrm{~nm}$ using a UV-VIS Spectrophotometer (SHIMADZU UV-1800). Sucrose content of the samples were determined using a calibration curve prepared with different sucrose concentrations ranging from $40-200 \mu \mathrm{gml}^{-1}$.

\section{Determination of inorganic phosphorus content}

Test samples were prepared by diluting $0.4 \mathrm{ml}$ of latex serum with $1.6 \mathrm{ml}$ of TCA. Inorganic phosphorus content was determined using the method described by Taussky and Shorr (1953). Absorbance of the samples were measured at $740 \mathrm{~nm}$ using a UV-VIS Spectrophotometer (SHIMADZU UV1800). Inorganic phosphorus content of the samples was determined using a calibration curve prepared with different potassium dihydrogen phosphate concentrations ranging from $10-50$ $\mu \mathrm{gml}^{-1}$.

\section{Determination of thiol content}

Test samples were prepared by diluting $1.0 \mathrm{ml}$ of latex serum with $1.0 \mathrm{ml}$ of TCA. Thiol content was determined using the method described by Boyne \& Ellman (1972). Absorbance of the samples was measured at $412 \mathrm{~nm}$ using a UV-VIS Spectrophotometer (SHIMADZU UV-1800). The concentration of thiol of the samples was determined using a calibration curve prepared with different glutathione (reduced) concentrations ranging from 1 $-5 \mu \mathrm{gml}^{-1}$. 
N P S N Karunarathne et al.

\section{Determination of polyphenol content}

Test samples were prepared by diluting $1.0 \mathrm{ml}$ of latex serum with $1.0 \mathrm{ml}$ of TCA. Modified Folin-Ciocalteus method was used to determine polyphenol contents of the samples (Turkmen et al., 2006). Absorbance of the samples were measured at $750 \mathrm{~nm}$ using a UV-VIS Spectrophotometer (SHIMADZU UV1800). The concentration of polyphenols of the samples were determined using a calibration curve prepared with different gallic acid concentrations ranging from 5 - $25 \mathrm{\mu gml}^{-1}$.

\section{Statistical analysis of data}

Data were analyzed using SAS software. ANOVA was done for the variables followed by mean separation using Least Significant Difference (LSD) at the significance level of 0.05 .

\section{Results and Discussion}

A similar variation of latex sucrose content could be observed in trees stimulated with both oil-based and water-based ethephon throughout the period tested (Fig. 1a). Generally, a decrease of latex sucrose content is observed under ethephon application as a result of the higher sucrose consumption in latex regeneration (Gohet et al., 2008). A significantly higher average sucrose content $(\mathrm{p}=0.027)$ was evident in trees stimulated with oil-based ethephon $(4.94 \pm 0.31 \mathrm{mM})$ than that with waterbased ethephon $(4.08 \pm 0.23 \mathrm{mM})$ during the first stimulation cycle (Fig. 1a). However, average sucrose content of both formulations showed no significant difference over the remaining period. A higher content of sucrose in latex may indicate a good loading to the laticifers (Jacob et al., 1989) which may positively effect on latex regeneration, ultimately the yield. Thus, higher latex sucrose content may indicate more sucrose recovery to the laticifers (Sainoi et al., 2017). Respectively, $1.41 \pm 0.22 \mathrm{mM}$ and $2.08 \pm 0.12 \mathrm{mM}$ were observed in oilbased stimulated and water-based stimulated trees as the lowest latex sucrose contents whilst $9.21 \pm 0.62 \mathrm{mM}$ and $7.42 \pm 0.19 \mathrm{mM}$ were the highest during the period.

Inorganic phosphorus content of latex is directly correlated with the latex production of trees and an indicator of energetic level of metabolism of latex cells (Jacob et al., 1989; Gohet et al., 2008). Pattern of variation of latex inorganic phosphorus content was similar with both types of ethephon (Fig. 1b). Over the three month period, waterbased formulation showed a higher monthly average latex inorganic phosphorous contents $(20.75 \pm 0.54 \mathrm{mM}$, $22.87 \pm 0.47 \mathrm{mM}, \quad 20.68 \pm 0.33 \mathrm{mM}$ ) compared to oil- based formulation $(16.93 \pm 0.50 \mathrm{mM}, \quad 18.56 \pm 0.71 \mathrm{mM}$, $17.07 \pm 0.55 \mathrm{mM})$ with a statistical significance $(p=0.000)$ (Fig. 1b). Highest and lowest inorganic phosphorous content in latex with water-based ethephon was $23.06 \pm 1.48 \mathrm{mM}$ and $13.56 \pm 2.74 \mathrm{mM}$ whilst it was $21.24 \pm 1.52$ $\mathrm{mM}$ and $16.02 \pm 2.24 \mathrm{mM}$ in oil-based ethephon, respectively. Significantly higher inorganic phosphorus content in rubber trees applied with water-based ethephon indicates a comparatively higher metabolic activation and energy consumption in latex regeneration with water-based ethephon. 

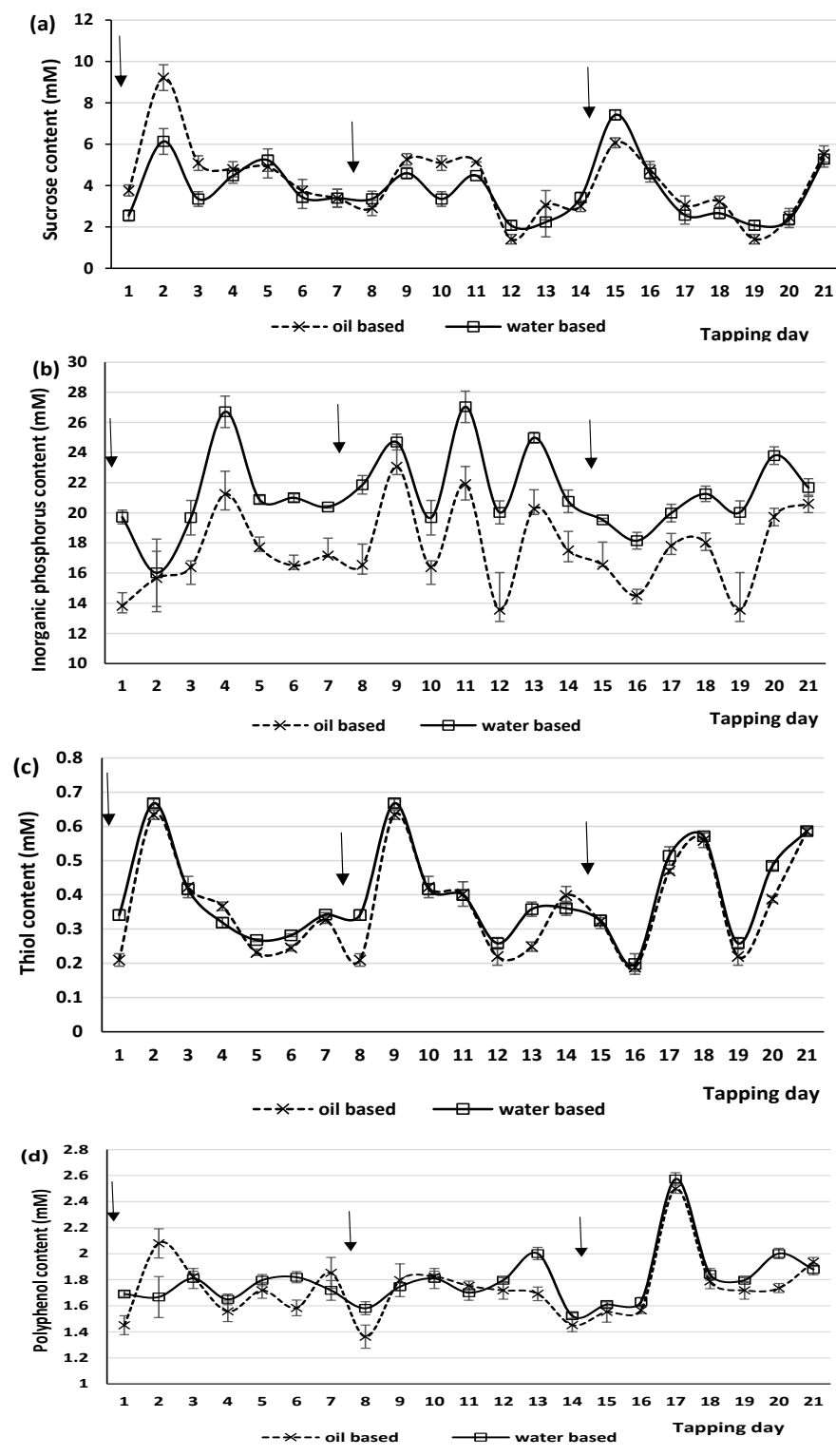

Fig. 1. Variation of latex (a) sucrose, (b) inorganic phosphorus, (c) thiol and (d) polyphenol content of rubber trees stimulated with different types of ethephon ('Arrow' mark indicates the day of stimulation)

Variations of thiol in water-based treatments were more or less similar with ethephon and oil-based ethephon no significant difference over the period 40 
N P S N Karunarathne et al.

investigated (Fig. 1c). Average values of latex thiol content of oil-based and water-based ethephon applied rubber trees were $0.35 \pm 0.02, \quad 0.37 \pm 0.02$, $0.39 \pm 0.02 \mathrm{mM}$ and $0.37 \pm 0.02$, $0.39 \pm 0.02,0.42 \pm 0.02 \mathrm{mM}$ over three stimulation cycles, respectively. In oilbased and water-based ethephon stimulated rubber trees, highest thiol content found was $0.63 \pm 0.01 \mathrm{mM}$ and $0.67 \pm 0.01 \mathrm{mM}$. For oil-based and waterbased ethephon treatments, the lowest thiol content was $0.19 \pm 0.01 \mathrm{mM}$ and $0.20 \pm 0.03 \mathrm{mM}$, respectively. Latex thiol content has a direct relationship with latex production. It was reported that thiols act as a potential activator for key enzymes such as invertase and pyruvate kinase (Jacob et al., 1989). Thiol also acts as an antioxidant that protects cells against damages caused by reactive oxygen species (De Costa et al., 2006).

Over three stimulation cycles, latex polyphenol contents in rubber trees treated with oil-based ethephon and water-based ethephon varied in a similar pattern with time and the difference between treatments was not statistically significant (Fig. 1d). The highest and lowest latex polyphenol contents found in oil- based stimulated trees were $2.50 \pm 0.04 \mathrm{mM}$ and $1.36 \pm 0.09 \mathrm{mM}$, respectively whilst it was $2.57 \pm 0.05 \mathrm{mM}$ and $1.58 \pm 0.05 \mathrm{mM}$ in trees applied with water-based ethephon over the period investigated. Higher phenols might be due to the reduced level of polyphenol oxidase enzyme which is a key enzyme in coagulation of latex (Coupe and Chrestin, 1989). On the other hand, higher polyphenol content in latex may result in latex discoloration in the presence of polyphenol oxidase enzyme (Yapa, 1976).

Plugging index of water-based ethephon and oil-based ethephon was statistically comparable. However, rubber trees stimulated with oil-based ethephon had a significantly higher latex flow duration than that of water-based ethephon in most of the tapping days $(\mathrm{p}<0.05)$ (Fig. $2 a$ and $b$ ).

With application of oil-based and waterbased ethephon, minimum plugging index of trees were reported as $1.73 \pm 0.13$ and $1.37 \pm 0.07$, respectively and it has been increased to the maximum values $3.27 \pm 0.23$ and $3.44 \pm 0.28$, respectively during the period investigated. Observed maximum and minimum flow durations were $176.7 \pm 1.8 \mathrm{~min}$ and $114 \pm 1.7 \mathrm{~min}$ in oil-based stimulated trees whilst $178.3 \pm 1.0 \mathrm{~min}$ and $126.3 \pm 1.4 \mathrm{~min}$ were in water-based stimulated trees, respectively (Fig. 2a and b).

Dry rubber content of latex was found to be significantly higher $(p<0.001$ in all stimulation cycles) in oil-based ethephon treated rubber trees than the water-based ethephon treated rubber trees over the period (Fig. 3a). Previous studies have also reported comparatively higher values of dry rubber content of latex with oil-based ethephon treated rubber trees (Kudaligama et al., 2013). Over the period tested, oil-based and water-based ethephon stimulated trees reported $46.23 \pm 0.12 \%$ and $42.60 \pm 0.13 \%$ as the highest dry rubber content, respectively and reported lowest DRC values were $39.50 \pm 1.63 \%$ and $36.67 \pm 0.06 \%$, respectively during the period (Fig. 3a). 

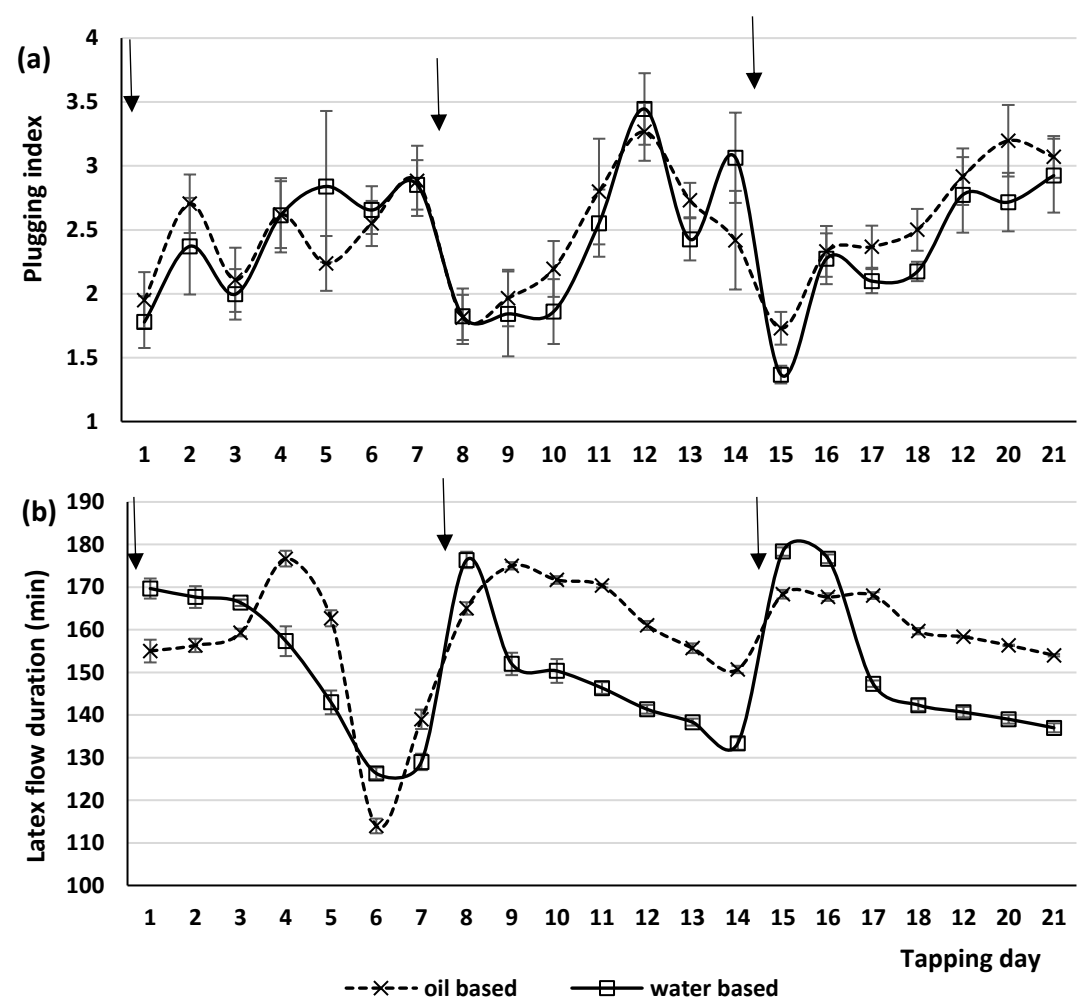

Fig. 2. Variation of (a) plugging index and (b) latex flow duration of rubber trees stimulated with oil- based and water- based ethephon formulations ('Arrow' mark indicates the day of stimulation)

Average DRC\% for three stimulation cycles were $43.80 \pm 0.37,42.69 \pm 0.47$, $42.13 \pm 0.50$ in oil-based ethephon stimulated trees whilst $40.63 \pm 0.36$, $39.39 \pm 0.42,39.59 \pm 0.36$ in water-based ethephon stimulated rubber trees. Drop in DRC\% was higher in water-based ethephon applied trees than in oil-based ethephon stimulated trees throughout the period.

Both latex volume per tree and dry rubber yield per tree per tapping $(\mathrm{g} / \mathrm{t} / \mathrm{t})$ showed a similar pattern of variation with oil-based ethephon and water-based ethephon treatments with no statistical significance (Fig. 3b and c). During three consecutive stimulation cycles, average values of latex volume of a tree were $171.24 \pm 11.61 \mathrm{ml}, 217.43 \pm 15.26 \mathrm{ml}$, $237.71 \pm 12.59 \mathrm{ml}$ and $161.43 \pm 11.96 \mathrm{ml}$, $220.86 \pm 15.65 \mathrm{ml}, 239.33 \pm 12.14 \mathrm{ml}$ with oil-based and water-based ethephon stimulated rubber trees, respectively. Respective average $\mathrm{g} / \mathrm{t} / \mathrm{t}$ values during the study were $92.15 \pm 4.99 \mathrm{~g}$ in oil-based ethephon stimulated rubber trees and $84.93 \pm 4.64 \mathrm{~g}$ in water-based ethephon stimulated rubber trees (Fig. $3 b$ and c). Peak $\mathrm{g} / \mathrm{t} / \mathrm{t}$ of oil-based ethephon stimulated trees was reported as 
$144.85 \pm 8.01 \mathrm{~g}$ and it was $133.37 \pm 16.19 \mathrm{~g}$ in water-based ethephon stimulated trees during the period.

Irrespective of the type of stimulant, the highest response for ethephon stimulant was observed on the very first tapping day ( $3^{\text {rd }}$ day after stimulation) after stimulation and then gradually decreased with time towards the next ethephon application.
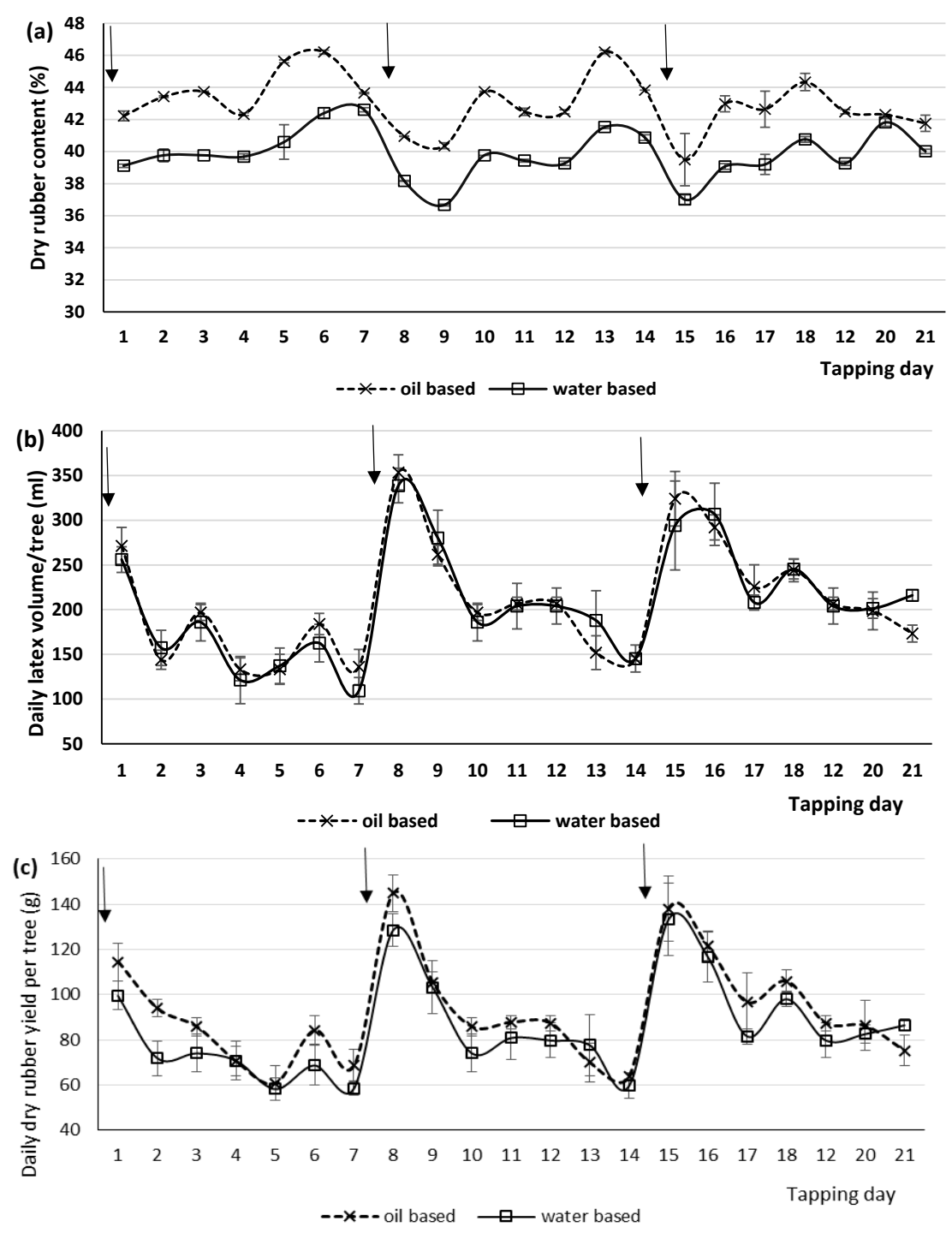

Fig. 3. Variation of (a) latex dry rubber content, (b) daily latex volume per tree and (c) daily dry rubber yield of trees stimulated with different types of ethephon ('Arrow' mark indicates the day of stimulation) 


\section{Conclusion}

Physiological parameters of latex of rubber trees showed some variations between oil-based ethephon and waterbased ethephon treatments. Though oilbased ethephon resulted a higher sucrose availability in laticifers on some tapping days, any positive effect on yield has not been observed. Higher inorganic phosphorous content in rubber trees stimulated with water-based ethephon indicates higher energy consumption in latex regeneration. As the yielding capacity of both ethephon types are similar, it can be presumed that oilbased ethephon is better performing as a long-term stimulant due to lesser requirement of energy consumption for latex production than the water-based ethephon. Extended latex flow duration by oil-based stimulation was more than that of water-based stimulation on most of the tapping days. This is an indication of the slow releasing effect of oil-based ethephon. Oil-based ethephon stimulated rubber trees resulted higher dry rubber content than the water-based stimulated rubber trees. However, yielding capacity did not vary significantly in trees applied with water-based and oil-based ethephon. Further studies are needed to investigate long term effects of these different ethephon formulations.

\section{Acknowledgements}

National Science Foundation of Sri Lanka is acknowledged for financial assistance provided under research grant RG/2017/AG/1 for the study. Valuable assistance of the staff of the Department of Biochemistry and Physiology and Dartonfield Estate of Rubber Research
Institute of Sri Lanka on research activities is highly appreciated. Authors wish to acknowledge Dr. Wasana Wijesuriya for her valuable guidance on statistical analysis.

\section{References}

Anon (1984). ISO standards Hand Book 22, Volume 1 and 2, International Standard Organization.

Boyne, A F and Ellman, G L (1972). A methodology for analysis of tissue sulfhydryl components. Analytical Biochemistry 46, 639-653.

Coupe, M and Chrestin, H (1989). Physicochemical and biochemical mechanisms of hormonal (ethylene) stimulation. In: Physiology of Rubber Latex, pp. 295-320 (Eds. D'Auzac, J., Jacob, J.L. and Chrestin, H.), CRC Press, Inc., Florida.

De Costa, C M, Dos Santos, R C C and Lima, E S (2006). A simple automated procedure for thiol measurement in human serum samples. Brazilian Journal of Pathology and Laboratory Medicine 42(5), 345-350.

Emuedo, O A, Omokhafe, K O, Ohikhena, F $\mathrm{U}$, Uzunuigbe, E O, Uwumarongie, A M D, Chukwuka, A N, Ugiagbe Ekue, U, Omorogbe, J A and Ehiwe, D (2017). Basal studies of Mortex as a latex yield stimulant of Hevea brasiliensis. Journal of Scientific and Engineering Research 4(12), 472-476.

Gao, L, Sun, Y, Wu1, M, Wang, D, Wei1, J, Wu1, B, Wang, G, Wu1, W, Jin, X, Wang, $\mathrm{X}$ and He, $\mathrm{P}$ (2018). Physiological and proteomic analyses of molybdenum- and ethylene-responsive mechanisms in rubber latex. Frontiers in Plant Science 9, 1-15.

Gohet, E, Scomparin, C, Cavaloc, E, Balerin, Y, Benites, G, Dumortier, F, Williams, H, Permadi, H P, Ginting, E, de Rostolan, E, Uche, E, Chegbene, P, Hocepied, E, Echimane, P, Soumahoro, M, Sargeant, H J, Suyatno, Najera C A, Soumahoro, B, 
N P S N Karunarathne et al.

Lacote, R and Eschbach, J M (2008). Influence of Ethephon Stimulation on Latex Physiological Parameters and Consequences on Latex Diagnosis Implementation in Rubber Agro-Industry. IRRDB Workshop on Latex Harvesting Technologies, 5-8 May 2008 Selangor, Malaysia.

Jacob, J L, Prevot, J C, Roussel, D, Lacrotte, R, Serres, E, d'Auzac, Eschbach, J M and Omont, H (1989). Yield- limiting factors, latex physiological parameters, latex diagnosis and clonal typology. In: Physiology of Rubber Latex, pp.345-382 (Eds. D'Auzac, J, Jacob, J L and Chrestin, H), CRC Press, Inc., Florida.

Kudaligama, K V V S, Rodrigo, V H L, Fernando, K M E P and Yapa, P A J (2010). Response of low frequency harvesting systems of rubber under drier climatic conditions in Sri Lanka. Proceedings of the $15^{\text {th }}$ International Forestry and Environment Symposium. Department of Forestry and Environmental Science, University of Sri Jayewardenepura, Sri Lanka. pp. 62-69.

Kudaligama, K V V S, Rodrigo, V H L, Fernando, K M E P and Yapa, P A J (2012). Low intensity harvesting of natural rubber: a financial perspective. Proceedings of the International Forestry and Environment Symposium. Department of Forestry and Environmental Science, University of Sri Jayewardenepura, Sri Lanka. pp. 91.

Kudaligama, K V V S, Rodrigo, V H L, Randunu, R P S and Rodrigo, P D J (2013). Preliminary investigations of an oil based ethephon mixture (Motex plus) on low intensity harvesting systems of rubber. Proceedings of International Forestry and Environment Symposium. Department of Forestry and Environmental Science, University of Sri Jayewardenepura, Sri Lanka. pp.111.

Mesquita, A C, Oliveira, L E M de,
Mazzafera, P and Delú-Filho, N (2006). Anatomical characteristics and enzymes of the sucrose metabolism and their relationship with latex yield in the rubber tree (Hevea brasiliensis Muell. Arg.). Brazilian Journal Plant Physiology 18, 263-268.

Milford, G F J, Paardekooper, E C and Ho, C $Y$ (1969). Latex vessel plugging its importance to yield and clonal behavior. Journal of the Rubber Research Institute of Malaya 21, 274-282.

Njukeng, J N, Muenyi, P M, Ngane, B K and Ehabe, E E (2011). Ethephon stimulation and yield response of some Hevea clones in the humid forests of South West Cameroon. International Journal of Agronomy 2011, 1-5.

Prasanna, W R A C, Rodrigo, V H L, Abeysinghe, D C and Kudaligama, K V V S (2010). Stimulant levels to be used with two low intensity harvesting (LIH) systems of rubber under wet and intermediate zones of Sri Lanka. Proceedings of the $15^{\text {th }}$ International Forestry and Environment Symposium. Department of Forestry and Environmental Science, University of Sri Jayewardenepura, Sri Lanka. pp. 265-272.

Rodrigo, V H L, Kudaligama, K V V S, Fernando, K M E P and Yapa, P A J (2011). Harvesting the rubber tree once in four days; a solution to current issues in the rubber industry in Sri Lanka. Journal of the Rubber Research Institute of Sri Lanka 91, 15-35.

Sainoi, T, Sdoodee, S, Lacote, R, Gohet, E and Chantuma, P (2017). Stimulation affecting latex physiology and yield under low frequency tapping of rubber (Hevea brasiliensis) clone RRIM 600 in Southern Thailand. Australian Journal of Crop Science 11(2), 220-227.

Scott, T A and Melvin, E H (1953). Determination of dextran with anthrone. Analytical Chemistry 25(11), 1656-1661. 
Shi, M J, Cai, F G and Tian, W M (2016). Ethrel -stimulated prolongation of latex flow in the rubber tree (Hevea brasiliensis Muell. Arg.): an Hev b 7-like protein acts as a universal antagonist of rubber particle aggregating factors from lutoids and Cserum. The Journal of Biochemistry 159(2), 209-216.

Taussky, H H and Shorr, E (1953). A micro colourimetric method for the determination of inorganic phosphorous. Journal of Biological Chemistry 202, 675685.

Tseng, S, Chang, P and Chou, S (2000). A rapid and simple method for the determination of ethephon residue in agricultural products by GC with headspace sampling. Journal of Food and Drug Analysis 8 (3), 213-217.

Tupy, J (1985). Some aspects of sucrose transport and utilization in latex producing bark of Hevea brasiliensis Muel. Arg. Biologia Plantarum 27, 51-64.

Turkmen, N, Sari, F and Sedat Velioglu, Y (2006). Effect of extraction solvents on concentration and antioxidant activity of black and black mate tea polyphenols determined by ferrous tartrate and folinciocalteu methods. Food Chemistry 99, 835-841.

Verheye, W (2010). Growth and production of rubber. In: Land Use, Land Cover and Soil Sciences, Encyclopedia of Life Support Systems (EOLSS), pp. 1- 20 (Eds. Verheye, W.), UNESCO-EOLSS Publishers, Oxford, UK.

Yapa, P A J (1976). Some aspects of phenolic discoloration in natural rubber. Journal of Rubber Research Institute Sri Lanka 53, 22-30.

Zhu, J and Zhang, Z (2009). Ethylene stimulation of latex production in Hevea brasiliensis. Plant Signaling and Behavior 4(11), 1072-1074.

Address for correspondence: Dr (Mrs) K V V S Kudaligama, Head, Biochemistry \& Physiology Dept., Rubber Research Institute of Sri Lanka, Dartonfield, Agalawatta, Sri Lanka,

e-mail: kudaligama.rrisl@gmail.com 